\title{
MANAGEMENT OF HUMAN RESOURCE DEVELOPMENTEDUCATION IN ELEMENTRAY SCHOOL
}

\author{
Maharani Nimasayu Hendraswari, Siti Sutarmi Fadhilah, Peduk Rintayati \\ Universitas Sebelas Maret \\ maharaninimasayu@gmail.ac.id
}

\begin{tabular}{l} 
Article History \\
\hline accepted 09/07/2018 \\
approved 01/08/2018 \\
published 17/09/2018
\end{tabular}

Keywords

management human resource development, education, training

\begin{abstract}
Management of human resource development in the field of education related to the role of the Principal in an effort to develop the potential that exist in educators and educational personnel. The purpose of this study is to determine the extent to which the role of Headmaster and the staff of educators and education at Kartodipuran elementary school number 21 Surakarta in an effort to explore the ability to support performance in working in the field of education. This research uses qualitative descriptive method with data collection through interview technique and documentation. The results of this study can be concluded that the principal, educators and education at Kartodipuran elementary school number 21 Surakarta has conducted various training and education activities such as job rotation, understudy, coaching and counseling, conference, outdoor training, training, simulations, lecture, self-study.
\end{abstract}

Social, Humanities, and Education Studies (SHEs): Conference Series https://jurnal.uns.ac.id/shes

p-ISSN 2620-9284 e-ISSN 2620-9292 


\section{PENDAHULUAN}

Masyarakat Indonesia sekarang ini berada pada erap disrupsi yaitu era yang mengubah perkembangan dunia secara cepat tanpa disangka. Di era ini menuntut masyarakat untuk terus maju, berkembang, dan membuat penemuan-penemuan yang baru agar dapat mengikuti arus dengan keterampilan yang dimiliki. Masyarakat perlu merubah pola pikir dan berusaha menyesuaikan dengan lingkungan yang baru, dimana perkembangan yang begitu cepat ditandai dengan kemajuan teknologi dan informasi sehingga masyarakat dapat bertahan dalam situasi dan kondisi yang berbeda dengan keadaan yang sebelumnya. Masyarakat yang tidak mampu beradaptasi akan mengalami kesulitan dalam lingkungan tersebut dan juga dalam menjalankan kegiatan sehari-hari. Semakin majunya teknologi dan informasi berdampak pada pengembangan sumber daya manusia sendiri untuk menggali kemampuan dan keterampilan yang selama ini belum terlihat. Dampak ini juga dirasakan dalam dunia pendidikan, dimana para tenaga pendidik dan tenaga kependidikan juga turut andil untuk mengembangkan potensi yang ada dalam diri mereka. Dengan mengembangan sumber daya manusia tenaga pendidik dan kependidikan nantinya dapat memfasilitasi dan membantu peserta didik dalam proses belajar mengajar. Selain itu juga dapat membantu peserta didik beradaptasi dan mampu bertahan dalam era distrupsi. Pendidikan memegang peranan penting dalam kehidupan berbangsa dan bernegara yaitu untuk menciptakan sumber daya manusia yang memili kualitas tinggi dan mampu bersaing.

Pengembangan Sumber Daya Manusia (SDM) merupakan bagian terintegrasi dari Manajemen SDM. Manajemen dan pengembangan SDM dalam suatu organisasi merupakan suatu sistem yang terintegrasi. Seperti yang telah dipelajari Manajemen SDM bahwa "Manajemen sumber daya manusia adalah proses merencanakan, mengorganisasikan, memimpin, dan mengendalikan seluruh kegiatan pengadaan tenaga kerja, pengembangan karyawan, pemberian kompensasi, pemeliharaan karyawan, dan pemutusan hubungan kerja berdasarkan ketentuan dan perundangan yang berlaku untuk mencapai sasaran dan tujuan individu karyawan, perusahaan, dan masyarakat". Pengembangan karyawan yang dimaksud pada dasarnya adalah pengembangan SDM dalam suatu organisasi. Pada umumnya, masih banyak di antara kita yang menganggap pengembangan SDM sebagai pelatihan dan pengembangan, pembelajaran, pengembangan karier.

Pembinaan dan pengembangan guru menurut Undang-Undang Nomor 14 Tahun 2005 tentang Guru dan Dosen disebutkan sebagai berikut: Pembinaan dan pengembangan guru meliputi pembinaan dan pengembangan profesi dan karier. Pembinaan dan pengembangan yang dimaksud dilakukan melalui jabatan fungsional yang terdiri atas penugasan, kenaikan pangkat, dan promosi. Ruang lingkup aspek yang dibina dan dikembangkan mencakup kompetensi pedagogik, kepribadian, sosial, dan profesional. Pembinaan dan pengembangan profesi dan karier guru pada satuan pendidikan diselenggarakan oleh pemerintah, pemerintah daerah, atau masyarakat yang ditetapkan melalui peraturan menteri. Dalam hal ini pemerintah pusat dan pemerintah daerah wajib membina dan mengembangkan kualifikasi akademik dan kompetensi guru pada satuan pendidikan yang diselenggarakan oleh pemerintah, pemerintah daerah, dan/ atau masyarakat. Pemerintah dan pemerintah daerah wajib memberikan anggaran untuk meningkatkan kualifikasi dan kompetensi akademik guru pada satuan pendidikan.

Pengembangan dan pelatihan merupakan dua konsep yang sama, yaitu untuk meningkatkan kemampuan yang bersifat pengetahuan, keterampilan, dan sikap agar pegawai bekerja lebih baik. Tetapi, dilihat dari tujuannya keduanya dapat dibedakan. Pengembangan difokuskan untuk meningkatkan kemampuan membuat keputusan dan keterampilan pada manajemen tingkat menengah dan atas, sedangkan pelatihan difokuskan pada pegawai yang lebih rendah untuk meningkatkan kemampuan 
melakukan pekerjaan yang lebih spesifik. Pelatihan dimaksudkan agar pegawai dapat melaksanakan tugas pekerjaan sesuai dengan standar kerja yang sedang berlangsung saat ini, sementara pengembangan untuk tujuan peningkatan kinerja dan keberlangsungan organisasi dalam jangka panjang. Umumnya pelatihan bisa digabung dengan program pengenalan pekerjaan sebelum pegawai melakukan kerja.

\section{Pengertian Manajemen Sumber Daya Manusia Pendidikan}

Manajemen dalam arti luas adalah perencanaan, pengorganisasian, pengarahan, dan pengendalian (P4) sumber daya organisasi untuk mencapai tujuan secara efektif dan efisien. Menuru Daryanto dkk, manajemen pendidikan dapat didefinisikan sebagai seni dan ilmu mengelola sumber daya pendidikan untuk menwujudkan suasana belajar dan proses pembelajaran agar peserta secara aktif mengembangkan potensi dirinya untuk memiliki kekuatan spiritual keagamaan, pengendalian diri, kepribadian, kecerdasan, akhlak mulia, serta keterampila yang diperlukan dirinya, masyarakat bangsa dan negara (2013: 1). Istilah sumber daya manusia menurut Nurul Ulfatin dkk (2016: 2) dapat diartikan dengan pekerja, pegawai atau karyawan, yaitu orang yang mengerjakan atau mempunyai pekerjaan. Pengembangan sumber daya manusia dalam (PSDM) dalam pendidikan pada dasarnya suatu bentuk usaha untuk meningkatkan daya tahan saing pendidikan terhadap ancaman lingkungan eksternal dan suatu usaha untuk meningkatkan daya inovatif untuk menciptakan peluang. Dengan demikian PSDM dalam pendidikan merupakan bentuk usaha pemgembangan yang bersifat integral baik yang menyangkut SDM sebagai individu dan sebagai sistem maupun organisasi sebagai wadah SDM untuk memenuhi kebutuhanya (Jumawan, 2015: 259). Manajemen sumber daya manusia pendidikan adalah segala kegiatan yang berkaitan dengan pengakuan akan pentingnya sumber daya manusia yang ada di sekolah sumber yang vital dan memberikan sumbangan bermakna terhadap pencapaian tujuan pendidikan, serta menjamin bahwa sumber itu dimanfaatkan secara efektif dan adil demi kemaslahatan individu, sekolah, dan masyarakat (Nurul Ulfatin dkk, 2016: 11).

Wina Sanjaya (2009) memaparkan ada empat bidang utama prinsip-prinsip manajemen sumber daya manusia yaitu:

1. Penerapan manajemen SDM untuk peningkatan fungsi administrasi dan operasi secara luas untuk mengelola sekolah secara keseluruhan.

2. Mengintegrasikan manajemen SDM dalam kurikulum, fungsi kurikulum dalam rangka pencapaian tujuan pendidikan, kurikulum dapat dipandang sebagai alat untuk pencapaian tujuan pendidikan nasional, dengan menjabarkannya secara berturut menjadi tujuan nasional, tujuan kurikuler, dan tujuan intruksional, pada setiap jenis dan jenjang lembaga pendidikan (Madrasah).

3. Pentingnya manajemen SDM dalam pengajaran di kelas, guru merupakan pendidik yang sangat mempengaruhi kepribadian peserta didik.

4. Manajemen SDM untuk mengelola aktivitas evaluasi sekolah.

Dari beberapa pengertian diatas dapat disimpulkan bahwa manajemen pengembangan sumber daya manusia pendidikan merupakan suatu perencanaan, penorganisasian, pengarahan, dan pengendalian agar memiliki tanggung jawab yang tinggi dalam memenuhi setiap kebutuhan untuk mencapai tujuan serta meningkatkan kualitas dan kuantitas manusia.

\section{Tujuan Manajemen Sumber Daya Pendidikan}

Dalam buku Manajemen sumber daya manusia bidang pendidikan, Nurul Ulfatin dkk mengungkapkan untuk mencapai kebermaknaan sumber daya manusia yang optimal, maka diperlukan manajemen dengan tujuan yang jelas. Tujuan manajemen dapat dilihat dari tingkat yang paling rendah yaitu tingkat personal (personal objective), naik ke tingkat yang lebih tinggi yaitu tujuan fungsional (fuctional objective), dilanjutkan ke tujuan organisasional (organizational objective), dan puncaknya untuk tujuan layanan masyarakat secara nasional dan internasional 
(society objective) (2016: 140). Tujuan personal (personal objective); yaitu membantu sumber daya manusia untuk mencapai tujuan dari individunya. Tujuan fungsional (fuctional objective) manajemen sumber daya adalah tujuan yang memelihara kontribusi bagian-bagian dalam organisasi agar sumber daya manusia pada bagian itu dapat menjalankan tugas secara optimal. Tujuan organisasional (organizational objective) manajemen sumber daya manusia yang tujuan terkait dengan tujuan keefektifan organisasi. Tujuan masyarakat (society objective), yaitu tujuan untuk memenuhi kebutuhan dan tantangan yang timbul di masyarakat, sehingga organisasi diharapkan dapat memberi manfaat atau keuntungan bagi masyarakat.

Sedangkan menurut Soekidjo Notoatmodjo (2003: 41) pada dasarnya tujuan pendidikan adalah suatu deskripsi dari pengetahuan, sikap, tindakan, penampilan dan sebagainya yang diharapkan akan memiliki sasaran pendidikan pada periode tertentu. Lahirnya tujuan pendidikan disebabkan karena diperlukannya suatu kurikulum yang efesien dan efektif. Maksud menetapkan tujuan pendidikan terlebih dahulu, agar memudahkan dan mengarahkan penyusunan kurikulum. meliputi:

Fungsi manajemen sumber daya manusia dalam (Leni Marlina, 2015) antara lain

1. Perencanaan, pengorganisasian, pengerahan, pengendalian, pengadaan, pengembangan, kompensasi, pengintegrasian, pemeliharaan, kedisiplinan, dan pemberhentian. kebutuhan perusahaan dalam membantu terwujudnya tujuan.

2. Pengorganisasian, adalah kegiatan untuk mengorganisasi semua karyawan dengan menetapkan pembagian kerja, hubungan kerja untuk mencapai tujuan.

3. Pengarahan (directing), adalah kegiatan mengarahkan semu karyawan, agar mau bekerja sama dan bekerja efektif serta efesien dalam membantu tercapainya tujuan perusahaan, karyawan, dan masyarakat.

4. Pengendalian (controlling), adalah kegiatan mengendalikan semua karyawan, agar mentaati peraturan-peraturan perusahaan dan bekerja sesuai dengan rencana.

5. Pengadaan (procurement), adalah proses penarikan, seleksi, penempatan, orientasi, dan induksi untuk mendapatkan karyawan yang sesuai dengan kebutuhan perusahaan.

6. Pengembangan (development), adalah proses peningkatan keterampilan teknis, konseptual, dan moral karyawan melalui pendidikan dan pelatihan. Pendidikan dan pelatihan yang diberikan harus sesuai dengan kebutuhan pekerjaan masa kini maupun masa depan.

7. Kompensasi (compensation), adalah pemberian balas jasa langsung (direct) dan tidak langsung (indirect), uang atau barang kepada karyawan sebagai imbalan jasa yang diberikan kepada perusahaan.

8. Pengintergrasian (integration), adalah kegiatan untuk mempersatukan kepentingan perusahaan dan kebutuhan karyawan, agar tercipta kerja sama yang serasi dan saling menguntungkan.

9. Pemeliharaan (maintenance), adalah kegiatan untuk memelihara atau meningkatkan kondisi fisik, mental, dan loyalitas karyawan, agar mereka tetap mau bekerja sam sampai pensiun.

10. Kedisiplinan, merupakan fungsi manajemn sumber daya manuisa yang terpenting dan kunci terwujudnya tujuan karena tanpa disiplin yang baik sulit terwujud tujuan yang maksimal.

11. Pemberhentian (separation), adalah putusnya hubungan kerja sesorang dari suatu perusahaan.

Metode Manajemen Pengembangan Sumber Daya Manusia Pendidikan

Pengembangan SDM khususnya di bidang pendidikan dapat dilakukan sesuai dengan penggunaan metode yang telah ditetapkan. Metode pengembangan dalam SDM di bidang pendidikan sangat diperlukan untuk mengetahui cara yang dapat 
dilakukan untuk mengembangkan kemampuan SDM di bidang pendidikan. Menurut Priansa, metode yang dapat dilakukan dapat dijelaskan sebagai berikut: (2014: 154):

1. Metode Pendidikan (Educating)

Metode pendidikan biasanya sebagai suatu metode pengembangan untuk pegawai manajerial. Tenaga manajerial adalah mereka yang mempunyai wewenang terhadap orang lain. Metode-metode yang digunakan berbeda dengan metode untuk pegawai operasional. Hal ini dikarenakan adanya perbedaan karakteristik kepribadian yang ada pada para manajer dan pegawai operasional.

Dengan metode pendidikan yang digunakan untuk mengembangkan SDM khususnya di bidang pendidikan, yang perubahannya dapat diliat dari perubahan tingkah laku pegawai tersebut. Tujuan pendidikan sendiri memuat deskripsi dari pengetahuan, sikap, tindakan, penampilan, dan sebagainya yang pada periode tertentu memiliki sasaran dalam pendidikan.

2. Metode Pelatihan (Training)

Metode satu ini yang digunakan dalam pengembangan SDM pendidikan dipilih berdasarkan kebutuhan dan kepentingan dari organisasi dan pegawai. Berbagai hal yang berhubungan dengan pelatihan misalnya menyangkut waktu pelaksanaan, biaya, jumlah peserta, tingkat pendidikan, latar belakang pegawai, dan berbagai hal lainnya terkait dengan pegawai.

Area dalam metode pelatihan lebih sedikit dibandingkan dengan pendidikan. Pelatuhan berdasarkan pandangan sebagai penerapan kecakapan dan keterampilan pekerjaan, oleh sebab itu pelatihan lebih focus terhadap bagaimana mempelajari dalam melaksanakan tugas-tugas khusus pada waktu tertentu. Pelatihan merupakan fungsi yang secara terus-menerus disesuaikan dengan area pekerjaan pegawai.

\section{Strategi Manajemen Pengembangan Sumber Daya Manusia Pendidikan}

Wayne E. Casio dalam Sedarmayanti (2011: 181) membagi dua jenis strategi pengembangan sumber daya manusia disesuaikan dalam bidang pendidikan dapat dilakukan dengan:

1. Pelatihan di tempat kerja (On the job training)

On the job training adalah strategi pengembangan sumber daya manusia informal yang memungkinkan seorang pegawai untuk dapat mempelajari tugastugas pekerjaannya dengan mengerjakan secara nyata. Kunci dari strategi ini adalah adanya transfer pengetahuan dari pegawai yang memiliki keterampilan dan berpengalaman kepada pegawai baru. Pelatihan ini dilaksanakan di tempat kerja dan dilakukan sembari bekerja. Para peserta pelatihan ini langsung bekerja di tempat untuk belajar dan meniru suatu pekerjaan di bawah bimbingan pengawas. On the job training dapat dilakukan dengan berbagai macam cara, yaitu:

a. Rotasi Pekerjaan (Job Rotation)

Rotasi pekerjaan (job rotation) adalah strategi pengembangan sumber daya manusia dimana para pegawai yang berpindah dari satu pekerjaan ke pekerjaan lainnya. Tujuan rotasi pekerjaan adalah untuk memperluas latar belakang pegawai dalam bekerja. Latihan ini membantu para pegawai untuk memahami berbagai macam pekerjaan dan menimbulkan saling ketergantungan diantara pegawai-pegawai tersebut. Rotasi pekerjaan sering digunakan oleh suatu lembaga untuk mendorong efektivitas kerja pegawai.

b. Bimbingan dan Penyuluhan (Coaching and Conseling)

Bimbingan (coaching) adalah jenis strategi pengembangan sumber daya manusia dalam pelatihan di mana atasan mengajarkan kepada bawahannya mengenai keahlian dan keterampilan. Supervisor diperlukan sebagai petunjuk untuk memberitahukan kepada pesertanya tentang tugas yang akan dilakukan dan bagaimana cara mengerjakannya. Coach sering dianggap sebagai pemegang tanggung jawab dari atasan dimana coach 
memberikan bantuan seperti mentor. Coach juga harus memiliki pengalaman yang lebih lama atau keahlian yang lebih tinggi dari bawahan. Coaching telah menjadi cara yang unggul di beberapa lembaga dalam pengembangan sumber daya manusianya. Sedangkan conseling adalah jenis pelatihan dengan cara diskusi antara pegawai dengan atasan mengenai hal-hal yang bersifat pribadi seperti aspirasi, keinginan bahkan ketakutannya.

c. Magang (Understudy)

Magang (understudy) adalah teknik pengembangan sumber daya manusia yang dilakukan dengan praktek langsung pegawai yang sudah dipersiapkan untuk menggantikan jabatan atasannya agar ia sudah terlatih apabila atasannya telah berhenti.

d. Demonstrasi dan Pemberian Contoh (Demonstration and Example)

Demonstration and example adalah pelatihan yang dilakukan dengan cara peragaan dan penjelasan langsung tentang cara mengerjakan suatu pekerjaan melalui contoh-contoh yang didemonstrasikan. Pelatihan ini sangat efektif karena selain peserta mendapatkan teori, mereka juga dapat melihat dan mempraktekannya secara langsung, sehingga antara teori dan kenyataan dapat langsung dipadukan.

2. Pelatihan di luar tempat kerja (Off the job training)

Off the job training adalah pelatihan yang dilakukan di tempat kerja terpisaah, di luar tempat kerja atau di luar waktu kerja. Tujuan dari off the job training ini adalah untuk meningkatkan pengetahuan dan keterampilan karyawan, agar para karyawan lebih memiliki kesempatan untuk bertukar pengalaman dengan karyawan lainnya dan agar para karyawan bisa mendapatkan ide-ide baru yang dapat mereka bawa ke tempat kerjanya. Off the job training terbagi menjadi dua jenis yaitu simulasi (simulation) dan presentasi informasi (information presentation) yang masing-masing dilakukan dengan berbagai macam cara, yaitu:

a. Simulasi (Simulation)

Simulasi (simulation) ini dilakukan dengan menggunakan alat atau mesin dalam kondisi lingkungan yang dibuat sama dengan yang sebenarnya meskipun sebenarnya hanyalah tiruan. Teknik simulasi dapat dilakukan dengan berbagai macam cara, yaitu:

1) Studi Kasus (Case Study)

Studi kasus (case study) adalah serangkaian fakta permasalahan yang disajikan dalam bentuk tertulis ataupun naratif yang harus dianalisis dan dipecahkan oleh peserta training. Kasus ini dapat digunakan untuk merangsang topik diskusi. Studi kasus memungkinkan peserta untuk menerapkan keahlian yang mereka miliki. Studi kasus dilaksanakan dengan cara peserta diminta untuk membahas masalah atau kasus tertentu dalam lembaga. Pembahasan dapat dilakukan secara tertulis maupun lisan. Kasus yang dibahas biasanya merupakan kasus nyata yang dikumpulkan dari beberapa lembaga.

Dengan adanya studi kasus, diharapkan kepada para karyawan untuk dapat meningkatkan kecakapan dan keterampilan yang merek miliki dalam mengambil keputusan dan juga menyadari bahwa keputusan yang diambilnya mempunyai dampak internal dan eksternal bagi lembaga.

2) Permainan Peran (Role Playing)

Permainan peran (role playing) adalah pelatihan dan pengembangan di mana para peserta diminta untuk merespon permasalahan khusus yang biasanya muncul di pekerjaan-pekerjaan mereka dengan meniru situasi di dunia nyata. Mereka bukan mendengarkan mentor berbicara mengenai cara menyelesaikan 
masalah dan mendiskusikannya tetapi mereka belajar dengan cara melakukannya (learning by doing). Pelatihan dengan cara ini telah sukses dilakukan oleh beberapa lembaga dalam mengajari para pegawainya berhubungan dengan orang-orang yang sedang marah, mengamuk bahkan lepas kendali. Tujuan utama dari pelatihan bermain peran ini adalah dapat menganalisis masalah antar pribadi dan memupuk keahlian dalam hubungan kemanusiaan.

3) Pelatihan Beranda (Vestibule)

Pelatihan beranda (ventibule) adalah pelatihan yang digunakan untuk menggambarkan dan memperkenalkan pekerjaan kepada pegawai baru dan melatih mereka untuk mengerjakan pekerjaan tersebut. Pelatihan ini membuat suatu duplikat dari bahan, alat dan kondisi yang akan mereka temui dalam situasi kerja yang sebenarnya. Penekanan dalam pelatihan ini lebih cenderung pada proses belajar dibandingkan produksi. Dengan cara ini peserta diharapkan dapat memperoleh tingkat kemahiran tertentu lebih cepat.

4) Pelatihan Laboratorium (Laboratory Training)

Pelatihan labolatorium ini dilaksanakan dengan cara membawa peralatan labolatorium dengan cara membawa membawa peserta ke dalam situasi di mana mereka dapat menyaksikan, merasakan dan mencoba sendiri peran mereka.

5) Pelatihan Sensitivitas (Sensitivity Training)

Pelatihan sensitivitas adalah pelatihan bagi para peserta pelatihan untuk meningkatkan sensitivitas antar mereka dengan menuntut diskusi yang terbuka dan jujur tentang perasaan, sikap dan perilaku mereka. Adanya pelatihan ini juga untuk memberitahukan kepada peserta yang lainnya secara jujur bagaimana perilakunya di mata orang lain dan perasaan orang lain mengenai perilaku tersebut. Diharapkan dengan adanya pelatihan ini para peserta pelatihan dapat lebih menyadari perasaan, sikap dan perilaku orang lain.

6) Pelatihan Alam Terbuka (Outbond)

Pelatihan alam terbuka (outbond) adalah pelatihan yang digunakan untuk menggambarkan program pengembangan sumber daya manusia yang berlangsung di alam terbuka yang meliputi pendakian gunung, pelayaran, arum jeram, sepeda gunung, dan lainlain. Tujuan dari pelatihan ini bukan tertuju kepada pengembangan keahlian teknis, namun lebih kepada pengembangan dan pengasahan keahlian antar pribadi, seperti keyakinan diri, penghargaan diri, tim kerja dan kepercayaan.

7) Pelatihan Keranjang Surat (In-Basket Training)

In-basket training adalah bentuk pelatihan di mana para peserta diminta untuk menangani sejumlah dokumen, pesan e-mail, memo, laporan dan pesan telepon. Peserta harus bertindak sesuai dengan informasi yang termuat dalam pesan-pesan tersebut.28

b. Presentasi Informasi (Information Presentation)

1) Kuliah (Lecture)

Kuliah (lecture) adalah pelatihan penyajian informasi secara lisan. Pelatihan ini dilakukan dengan cara ceramah atau pidato dari pelatih yang diucapkan secara ilmiah yang bertujuan untuk pengajaran. Pelatihan kuliah ini adalah pelatihan yang paling umum digunakan oleh lembaga. Pelatihan ini menitikberatkan pada penyajian materi yang bersifat teori.

2) Seminar (Conference) 
Seminar dilakukan dengan cara berkelompok lalu berdiskusi dan diawasi oleh evaluator. Setelah diskusi selesai, evaluator mengukur dan menilai hasil diskusi yang telah dilakukan peserta.

3) Presentasi Video (Video Presentation)

Presentasi video dilakukan dengan tujuan agar yang bersangkutan dapat melihat kembali apa yang telah dilakukan agar dapat dijadikan pelajaran dan penyempurnaan.

4) Belajar Mandiri (Self Study)

Belajar mandiri adalah upaya pegawai untuk mendapatkan informasi dan pengetahuan sebanyak mungkin sesuai dengan kebutuhan tanpa adanya instruksi.

5) Tugas Baca dan Riset yang Diawasi (Supervised Reading and Research)

Tugas baca dan riset yang diawasi adalah tugas dan kewajiban yang harus dilakukan oleh karyawan sesuai dengan persetujuan yang telah disepakati.

\section{Jenis-Jenis Manajemen Pengembangan Sumber Daya Manusia Pendidikan}

I Ketut Sudarsana (2012) berpendapat jenis-jenis kegiatan pendidkan luar sekolah dalam pengembangan sumber daya manusia sebagai suplemen dari pendidikan persekolahan sangat bervariasi, seperti pelatihan kejuruan, kursus, magang dalam bidang pertanian, industri, pertukangan, pengetahuan kerumahtanggaan. Peran pendidikan luar sekolah sebagai komplemen pendidikan persekolahan berarti pelengkap. Jadi pendidkan luar sekolah sebagai komplemen adalah melengkapi apa-apa yangdiajarkan dalam pendidikan persekolahan.

Menurut Nurul Ulfatin (2016: 141) setiap pegawai tentu menginginkan kariernya meningkat. Peningkatan karier ditandai dengan peningkatan tanggung jawab terhadap suatu tugas dan diikuti peningkatan kompensansi yang diterimanya. Agar karier pegawai mengalami peningkatan, maka ia harus memiliki perencanaan dan pengembangan karier yang jelas. Pengembangan karier bisa dilakukan melalui dua jalur, yaitu (1) pendidikan dan pelatihan (diklat), (2) non diklat.

Kadarisman (2013: 38) menyebutkan bahwa pengembangan pegawai dapat ditempuh baik secara formal maupun non formal. Pengembangan secara formal, yaitu pegawai ditugaskan organisasi untuk mengikuti pendidikan atau latihan, baik yang dilakukan organisasi maupun yang dilaksanakan oleh lembaga-lembaga pendidikan dan pelatihan. Pengembangan secara formal dilakukan organisasi karena tuntutan organisasin saat ini maupun masa datang, yang sifatnya nonkarier atau peningkatan karier seorang pegawai. Sedangkan pengembangan informal, yaitu pegawai atas keinginan sendiri dan usaha sendiri melatih dan mengembangkan dirinya dengan mempelajari buku-buku literatur yang ada hubungannya dengan pekerjaan dan jabatan. Pengembangan secara informal, dalam bentuk pembelajaran, menunjukkan bahwa pegawai tersebut berkeinginan keras untuk maju dengan cara meningkatkan kemampuan kerjannya. Hal ini bermanfaat bagi organisasi karena prestasi kerjanya kerja pegawainya semakin besar, disamping efisien dan produktivitasnya juga semakin baik.

Menurut H. Abdul. Wahid Tahir (2017) Implementasi Manajemen SDM dalam peningkatan mutu merupakan sebuah sistem pendekatan dalam upaya memaksimalkan daya saing melalui perbaikan secara berkesinambungan (terus menerus) untuk memperoleh nilai atau mutu yang optimal atas jasa, manusia, produk dan lingkungan dengan melibatkan keseluruhan unsur dan stakeholders organisasi di bawah satu visi bersama. Peningkatan mutu pendidikan adalah suatu proses kerja yang lebih efektif dan efisien yang diikuti oleh sumber daya manusia yang berkompeten dengan loyalitas dan daya juang yang tinggi, sudah tentu akan 
menghasilkan peningkatan kinerja yang berujung pada kepuasan konsumen atau pelanggan.

Jadi dapat disimpulkan dari beberapa pendapat para ahli diatas bahwa jenis-jenis dari manajemen pengembangan sumber daya manusia pendidikan adalah pendidikan dan pelatihan (diklat) dan non diklat.

\section{METODE}

Metode penelitian yang digunakan adalah dengan metode deskriptif kualitatif. Metode ini menjelaskan bahwa peneliti menggali kejadian-kejadian yang dapat dikategorikan yang bersifat deskriptif. Dalam hal ini karena menggunakan teknik pengumpulan menggunakan wawancara, dokumentasi, angket, dan studi kepustakaan. Wawancara dilakukan dengan kepala sekolah, tenaga pendidik dan kependidikan di SDN Kartodipuran No. 21 Surakarta. Dokumentasi dilakukan dengan mengambil hasil foto sebagai bukti telah melakukan wawancara. Angket diberikan tenaga pendidik dan tenaga kependidikan yang isinya perihal pengetahuan tentang kegiatan, pelatihan dan pendidikan yang pernah dilakukan dan diamati terkait dengan manajemen pengembangan sumber daya manusia pendidikan. Studi kepustakaan adalah kegiatan untuk mengumpulkan beberapa referensi dari pengertian, konsep dan informasi dari jurnal, buku, e-book atau sumber internet yang terpercaya. Dalam kegiatan studi kepustakaan, setelah peneliti mendapat referensi dari berbagai sumber yang akurat dari berbagai ahli, peneliti dengan menggunakan kata-kata sendiri merangkai kembali beberapa konsep dan pengertian yang didapat menjadi sebuah simpulan yang sesuai dengan isi sumber yang didapatkan

\section{HASIL DAN PEMBAHASAN}

Berdasarkan wawancara, observasi, dan pengambilan data angket yang dilakukan peneliti dengan kepala sekolah dan guru kelas V SD Negeri Kartodipuran No. 21 tahun ajaran 2017/2018 diperoleh hasil sebagai berikut: Pelatihan dan pendidikan yang dilakukan oleh Kepala Sekolah dan guru di SD tersebut sudah baik, sehingga dapat memperoleh pengetahuan dan pengalaman yang baru guna menunjang pekerjaan dan pendidikannya di bidang pendidikan, penyelenggaraan dari proses pengembangan sumber daya manusia pendidikan biasanya dilakukan oleh pihak sekolah sendiri atau dari pemerintah, Kendala yang dihadapi dalam hal pengembangan sumber daya manusia pendidikan bisa dilihat dari segi usia para pegawai, lalu juga perbedaan penyampaian antara yang telah diajarkan di pelatihan dengan keadaan aslinya, Antusiasme dan semangat dari para tenaga pendidik dan pendidikan di sekolah ini membuktikan bahwa adanya ketertarikan dan minat dalam upaya mengempangkan potensi dalam diri guna mendukung kemudahan dalam bekerja dan bermasyarakat, implementasi setelah diadakannya pengembangan sumber daya manusia pendidikan juga bermanfaat bagi peserta didik dan rekan-rekan kerja yang lain, karena dapat memberikan pengalaman dan pengetahuan yang sebelumnya belum mereka ketahui dan dapatkan.

\section{SIMPULAN}

Manajemen sumber daya manusia pendidikan adalah segala kegiatan yang berkaitan dengan pengakuan akan petingnya sumber daya manusia yang ada di sekolah sebagai sumber yang vital dan memberikan sumbangan bermakna terhadap pencapaian tujuan pendiidkan, serta menjamin bahwa sumber itu dimanfaatkan secara efektif dan adil demi kemaslahatan individu, sekolah dan masyarakat.

Sumber daya manusia (SDM) adalah aspek penting dalam setiap kegiatan disuatu lembaga atau organisasi. Sumber daya manusia (SDM) ini dapat berfungsi secara optimal jika dikelola dengan baik. Oleh karena itu diperlukan manajemen (pengelolaan). Pengelolaan sumber daya manusia merupakan aspek yang sangat 
penting dalam proses pendidikan secara umum. Oleh karena itu fungsi-fungsi dalam pengelolaan sumber daya manusia harus dilaksanakan secara optimal, sehingga kebutuhan yang menyangkut tujuan individu, perusahaan, organisasi ataupun kelembagaan dapat tercapai.

Metode Pengembangan Sumber Daya Manusia Pendidikan yaitu: metode pendidikan (educating), metode pendidikan biasanya sebagai suatu metode pengembangan untuk pegawai manajerial dan metode pelatihan (training), metode pendidikan biasanya sebagai suatu metode pengembangan untuk pegawai manajerial.

Strategi Pengembangan Sumber Daya Manusia Pendidikan yaitu: pelatihan di tempat kerja (on the job training) adalah strategi pengembangan sumber daya manusia informal yang memungkinkan seorang pegawai untuk dapat mempelajari tugas-tugas pekerjaannya dengan mengerjakan secara nyata. Misalnya: rotasi pekerjaan (Job Rotation), bimbingan dan penyuluhan (Coaching and Conseling), magang (Understudy), demonstrasi dan pemberian contoh (Demonstration and Example). Dan selanjutnya pelatihan di luar tempat kerja (off the job training) adalah pelatihan yang dilakukan di tempat kerja terpisaah, di luar tempat kerja atau di luar waktu kerja. Misalnya: simulasi (simulation) yang dibagi lagi menjadi studi kasus (case study), permainan peran (role playing), pelatihan beranda (vestibule), pelatihan laboratorium (laboratory training), pelatihan sensitivitas (sensitivity training), pelatihan alam terbuka (outbond), pelatihan keranjang surat (in-basket training). Presentasi informasi (information presentation) yang dibagi lagi menjadi kuliah (lecture), seminar (conference), presentasi video (video presentation), belajar mandiri (self study), tugas baca dan riset yang diawasi (supervised reading and research)

Jenis-jenis dari manajemen pengembangan sumber daya manusia pendidikan adalah pendidikan dan pelatihan (diklat) dan non diklat.

\section{DAFTAR PUSTAKA}

Daryanto, dkk. (2013). Manajemen Pendidikan di Sekolah. Yogyakarta: Gaya Media.

Departemen Pendidikan Nasional, (2005). Undang-Undang Nomor 14 Tahun 2005: Tentang Guru dan Dosen. Jakarta: Depdiknas

Jumawan. (2015). Mengembangkan Sumber Daya Manusia (HRM) yang Strategis untuk Menunjang Daya Saing Organisasi: Perspektif Competency \& Talent Management. Media Mahardika, 13, (3), 258-269.

Kadarisman. (2013). Manajemen Pengembangan Sumber Daya Manusia. Jakarta: Raja Grafindo Persada.

Ketut I Sudarsono. (2012). Peningkatan Mutu Pendidkan Luar Sekolah Dalam Upaya Pembangunan Sumber Daya Manusia. Jurnal Penjaminan Mutu. 1, (1).

Marlina, L. (2015). Manajemen Sumber Daya Manusia (SDM) dalam Pendidikan. 15, 123-139.

Notoatmodjo, Soekidjo. (2009). Pengembangan Sumber Daya Manusia. Jakarta: Rineka Cipta.

Priansa, D, J. (2014). Perencanaan \& Pengembangan Sumber Daya Manusia. Bandung: Alfabeta.

Sanjaya, W. (2005). Perencanaan dan Desain Sistem Pembelajaran. Jakarta: Kencana.

Sedarmayanti. (2011). Manajemen Sumber Daya Manusia, Reformasi Birokrasi dan Manajemen Pegawai Negeri Sipil. Bandung: Refika Aditama.

Ulfatin, N, \& Triwijayanto, T. (2016). Manajemen Sumber Daya Manusia Bidang Pendidikan. Jakarta: Grafindo Persada.

Wahid. T, A. (2017). Pengembangan Manajemen Sumber Daya Manusia Terhadap Peningkatan Mutu Pendidikan. Jurnal UIN Alauddin. 1, (1). 1-14. 